\title{
FAECAL BACTERIA IN Perna perna (LINNAEUS, 1758) (MOLLUSCA: BIVALVIA) FOR BIOMONITORING COASTAL WATERS AND SEAFOOD QUALITY*
}

\author{
Diego Igawa Martinez and Ana Júlia Fernandes Cardoso de Oliveira \\ Universidade Estadual Paulista "Júlio de Mesquita Filho" - UNESP \\ Campus Experimental do Litoral Paulista \\ (Praça Infante Dom Henrique, s/nº $11330-900$ São Vicente, SP, Brasil) \\ e-mail: diegoigawa@clp.unesp.br
}

\begin{abstract}
A B S T R A C T
Urban development in coastal areas is intense and leads to the increase of sewage outfall and other negative impacts as consequences. Thus, stringent regulations establishing limits to the microbiological contamination of water and seafood are needed. The objective of this study is to evaluate the usefulness of Enterococci and Thermotolerant Coliform densities in the flesh of mussels Perna perna as an alternative tool for monitoring the microbiological quality of coastal waters. The study also considers allometric relations applied to clearance rates to understand rates of bacterial concentration. Bacterial loads obtained in mussels' flesh were from 50 to 4,300 times greater than in the water sampled in the vicinity of the mussels and some were considered inappropriate for consumption even when the water presented no restrictions. The mean clearance rate obtained for Enterococci retention was $317.7 \mathrm{ml} \mathrm{h}^{-1}$ and this rate $(C R)$ is related to the mussels's size $(L)$ by the equation $C R=28.3229 L^{1.6421}$. The results showed that bacterial densities in the mussels' tissues may reflect chronic contamination of the environment and that clearance rates are important for taking the best decision in situations where, for example, it is desired to introduce mussels for aquaculture and the evaluation of the water concerned is required.
\end{abstract}

\section{RESUMO}

O desenvolvimento urbano em áreas costeiras é intenso e o aumento das descargas de esgoto é uma das consequiências. Assim, leis específicas que regulem limites para a contaminação microbiológica das águas e de alimentos de origem marinha são necessárias. O objetivo deste estudo é avaliar a utilização de Enterococos e coliformes termotolerantes na carne de mexilhões Perna perna como alternativa para o monitoramento da qualidade microbiológica de águas costeiras. $\mathrm{O}$ estudo também considera relações alométricas aplicadas às taxas de "clearance" para entender a concentração de bactérias pelo molusco. As densidades bacterianas obtidas no molusco foram de 50 a 4300 vezes maiores do que nas amostras de água coletadas próximas dos moluscos e alguns foram considerados impróprios para consumo, mesmo quando as águas não mostraram restrições. A taxa de "clearance" média obtida para retenção de Enterococos foi $317.7 \mathrm{ml} \mathrm{h}^{-1}$ e essas taxas $(C R)$ puderam ser relacionadas com o tamanho dos mexilhões $(L)$ pela equação $C R=28.3229 L^{1.6421}$. Os resultados mostram que as densidades bacterianas nos tecidos dos mexilhões podem refletir a contaminação crônica do ambiente e que as taxas de "clearance" devem ser consideradas para a tomada de decisão em situações onde, por exemplo, se deseja implantar mexilhões para cultivo.

Descriptors: Perna perna, Fecal bacteria, Enterococci, Thermotolerant Coliforms, Clearance, Biomonitoring.

Descritores: Perna perna, Bactérias fecais, Enterococos, Coliformes Termotolerantes, Clearance,

Biomonitoramento.

\section{INTRODUCTION}

Coastal regions are complex and usually concentrate high population density and intense urban development. This development is not always associated with infra-structure and sanitary policies and results in the discharge of untreated sewage

(*) Paper presented at the Brazilian Symposium of Oceanography, 4. São Paulo, IOUSP, 08-12 December, 2008. directly into the sea. Such outfalls transport a variety of pathogenic microorganisms (WHO, 1998) and thus constitute a public health concern.

The contamination of waters and environmental degradation may also harm the economy of coastal cities and negatively affect tourism and compromise fisheries (COLLINS et al., 1998). In this context, monitoring the pollution of coastal sea waters by chemical and/or microbiological pollutants is a highly important task (OLIVEIRA et al., 2007). 
In the approach to monitoring, it must be admitted that it is inconceivable that all microorganisms that might be carried by sewage into coastal areas should be analyzed. Hence, an alternative is to search for microorganisms whose very presence indicates fecal contamination and the possible presence of pathogens (CETESB, 2006).

It has been observed (DE DONNO et al., 2008) that shellfish may contain high densities of fecal indicator bacteria, even when the surrounding waters are, apparently, of good quality. This suggests that bivalves such as mussels may concentrate pathogenic microorganisms in their tissues and that bacteria may have higher survival rates inside the bivalves (SOLIC et al., 1999).

Bacterial concentration by mussels is the result of physiological processes that control filtration rates, retention and excretion (SOLIC et al., 1999). Physiological rates, such as that of filtration, are also related to the size of the organism. It is, thus, possible to establish allometric equations relating these variables.

The knowledge of bivalves' filtration rates allows the clearance rates, variables which measure how many particles (including bacteria) are removed from water over time by the filtration process, to be calculated. These clearance rates may also be related to a biometric variable such as size or weight (RESGALLA JR. et al., 2006). Knowledge of this relation could be important for preventive actions in public health, particularly in respect to the consumption of mussels as seafood.
In the light of these implications, alternatives to monitoring safe levels of microorganisms introduced into sea water may be of value. We suggest that Enterococci densities in sessile filtrating organisms, such as the mussel Perna perna, might represent an interesting approach for evaluating chronic sea water contamination and seafood quality.

$P$. perna was chosen for this study because of its abundance and wide distribution and because it is frequently commercialized and consumed as food along the Brazilian coast and may represent an important economic and nutritional resource for some low income populations living in coastal areas of the country (JORGE et al., 2002).

So the first objective of this study is to determinate fecal bacteria (Thermotolerant coliform and Enterococci) densities in mussels and in the surrounding water simultaneously, in an attempt to correlate them and also to compare the bacterial densities found with those of Brazilian microbiological guidelines. The second objective is to determine, experimentally, allometric relations with clearance rates for the mussels collected off the cities of Santos and São Vicente, São Paulo - Brazil.

\section{Material and Methods}

Samples were collected monthly, from May to September, at low tide, on two rocky shores of coastal islands of the Baixada Santista region (Urubuqueçaba and Porchat Island), off the cities of São Vicente and Santos, São Paulo - Brazil (Fig. 1).

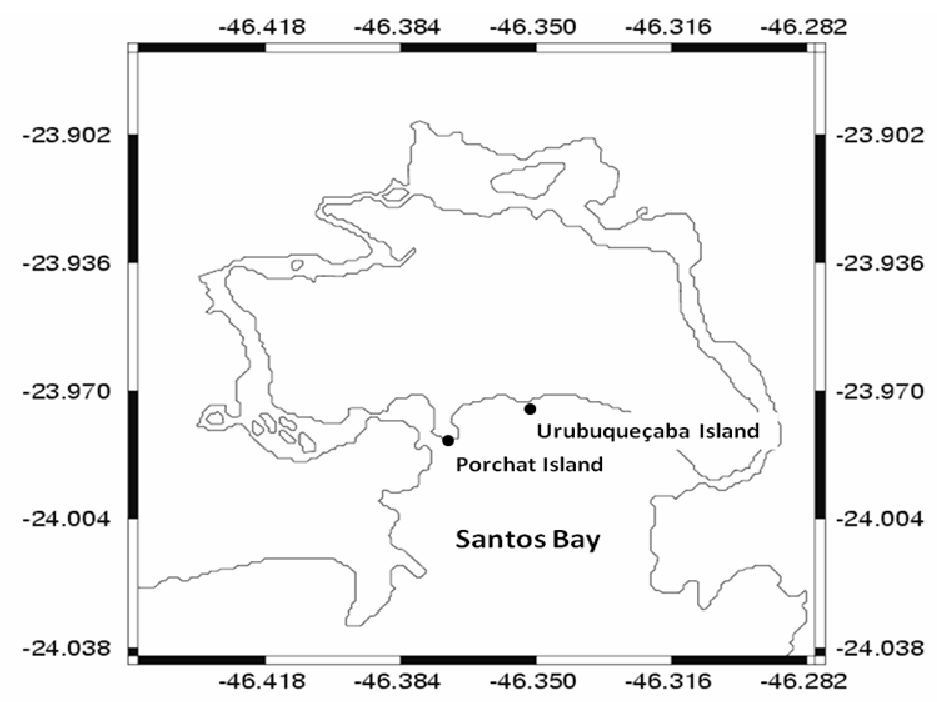

Fig. 1. Map showing the cities of São Vicente and Santos, marks show Porchat and Urubuqueçaba Islands. 
Mussels were collected during the same tide at both locations. Water samples were collected in the vicinity of the mussels, in sterile flasks. All the samples were placed in isothermic boxes and taken to the laboratory.

For bacteriological determinations, the mussel samples were homogenized with a sterilized blender with the addition of sterile buffered water solution in the proportion of 1:10.

Enterococci were determined by the $f$ Membrane Filtration Method (MF) (APHA, 2005) using mEnterococcus media (Difco). For the water samples, the filtered volumes were of 5 and $50 \mathrm{ml}$. For the mussels, the homogenized samples were serially diluted, to $10^{-2}$, in sterile buffered water and then volumes of 1 and $5 \mathrm{ml}$ were filtered.

The confirmation of the genus Enterococcus was made by using Enterococosel Broth (Becton Dickinson) (APHA, 2005).

The results were expressed as Colony Forming Units per $100 \mathrm{ml}\left(\mathrm{CFU} 100 \mathrm{ml}^{-1}\right)$ and as Colony Forming Units per $\mathrm{g}\left(\mathrm{CFU} \mathrm{g} \mathrm{g}^{-1}\right)$ for water and mussel samples, respectively.

Thermotolerant coliform determinations in water and mussel samples were made by the Most Probable Number method (MPN) (APHA, 2005) using as culture media Lauryl Tryptose Broth, Brilliant Green Bile (2\%) Lactose Broth (BRILA) and the Escherichia coli Broth (EC).

The results are expressed as the Most Probable Number per $100 \mathrm{ml}\left(\mathrm{MPN} 100 \mathrm{ml}^{-1}\right.$ ) and as the Most Probable Number per gram (MPN g ${ }^{-1}$ ).

Regression analysis was carried out to evaluate the relationship between the bacterial densities obtained from the water and those from the mussel samples over the period of the study, using BioEstat 5.0 software.

For the determination of the clearance rates, the methods of Resgalla Jr. et al. (2006) were used. Mussels were collected, measured (length of the shell, L) and then classified in five size classes: $\mathrm{L}<3.5 \mathrm{~mm}$; $3.5 \leq \mathrm{L}<4.0 \mathrm{~mm} ; 4.0 \leq \mathrm{L}<4.5 \mathrm{~mm}, 4.5 \leq \mathrm{L}<5.0$ $\mathrm{mm}$ and $\mathrm{L} \geq 5.0 \mathrm{~mm}$.

Experiments were carried out in duplicate. Mussels of each size class were placed in flasks containing $500 \mathrm{ml}$ of sterile sea water, filtered through $0.22 \mu \mathrm{m}$ membranes and autoclaved. Only one mussel was placed in each flask and these were maintained for two days under constant aeration, temperature and salinity $\left(20 \pm 2{ }^{\circ} \mathrm{C}\right.$ and 35 , respectively). Two other flasks, under the same conditions but without mussels, were used as controls.

After the acclimation period, a bacterial suspension of $10^{6}$ Enterococci per milliliter was added to each flask. These suspensions were obtained by culturing Enterococci isolated from sea water samples.
This value was used because it is the usual bacterioplankton density found in coastal waters.

The experiments were conducted for a period of three hours. Immediately after the addition of the bacterial suspension, $15 \mathrm{ml}$ was taken from each flask with a sterile pipette and dispensed in a sterile flask containing formaldehyde $(5 \%$ of final concentration) for bacterial number determination by direct counting under the epifluorescence microscope, in accordance with Hobbie et al. (1977).

This was taken as the initial time of the experiment $(\mathrm{t} 0)$. Each subsequent hour, $15 \mathrm{ml}$ was taken again from each flask and fixed in formaldehyde, thus constituting the subsamples for the experiment times 1,2 and 3 (t1, t2 and $\mathrm{t} 3$ ).

Clearance rates were calculated with the equation (RESGALLA JR. et al., 2006):

$$
C R=\frac{V}{N} \times\left\{\left[\frac{(\operatorname{LnCt0}-\operatorname{LnCt1})}{\Delta T}\right]-f\right\}
$$

where: $\mathrm{CR}=$ clearance rate $\left(\mathrm{ml}^{-1} \mathrm{~h}^{-1}\right) ; \mathrm{Ct}_{0}=$ initial bacterial concentration; $\mathrm{Ct}_{1}=$ final bacterial concentration; $\mathrm{V}=$ flasks volume $(\mathrm{ml}) ; \mathrm{N}=$ number of organisms per flask; $\mathrm{T}=$ experiment time $(\mathrm{h}) ; f=$ correction factor calculated using the same equation for the control flasks.

Results underwent logarithmic
transformation and were related to the mussels size with a least square regression to obtain an allometric relation between these variables.

\section{RESULTS}

Thermotolerant coliform densities of the water samples collected on Urubuqueçaba Island varied from zero to $11 \mathrm{MPN} 100 \mathrm{ml}^{-1}$, with a mean value ( \pm standard deviation) of $4.02( \pm 4.5)$, while the mussel samples presented densities of zero to 140 MPN g ${ }^{-1}$, with a mean value of $54.8( \pm 73.3)$ (Fig. 2a). In the Porchat Island samples, Thermotolerant coliform densities in the water varied from zero to $8 \mathrm{MPN} 100 \mathrm{ml}^{-1}$, with a mean value of $5.11( \pm 3.65)$. In the mussels, bacterial densities varied from zero to $49 \mathrm{MPN} \mathrm{g}^{-1}$, with a mean value of 17.3 $( \pm 22.43)$ (Fig. 2b).

In general, mussels from Urubuqueçaba Island showed higher Thermotolerant coliform densities than the mussels from Porchat Island. However, in the water samples collected in June and July, the Thermotolerant coliform densities were higher on Porchat Island. 


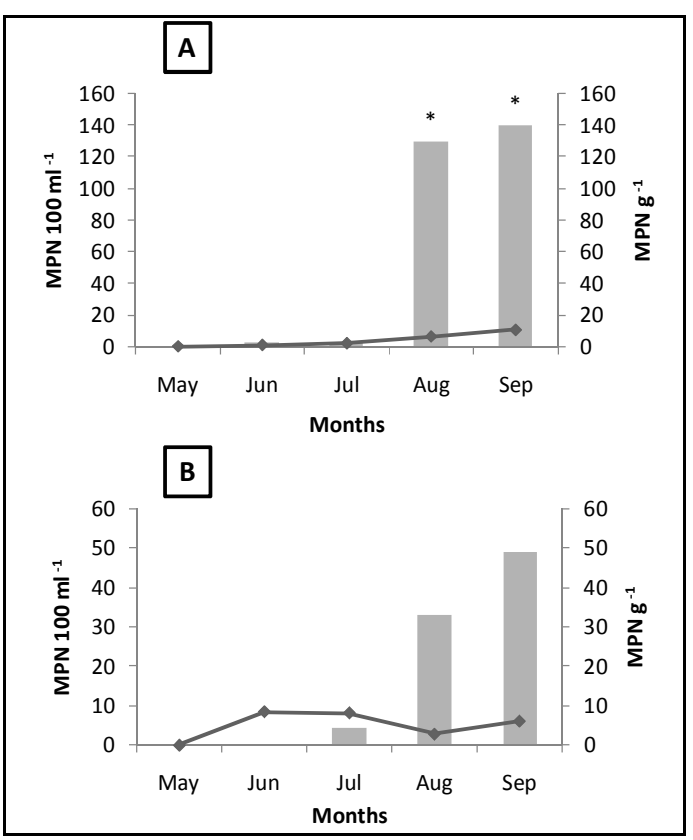

Fig. 2. Thermotolerant coliform densities obtained during the study. a) Samples from Urubuqueçaba Island. b) Samples from Porchat Island. Lines represent the results for water samples (MPN $100 \mathrm{ml}^{-1}$ ) and the bars represent the results for the mussels $\left(\mathrm{MPN} \mathrm{\textrm {g } ^ { - 1 }}\right){ }^{*}=$ Thermotolerant coliforms densities above the indicative limit for inappropriate sample, according to Resolution ANVISA RDC n 12/01.

Based on microbiological contamination, no water sample showed any restriction for recreational use or for bivalve culturing, according to the Brazilian regulations (CONAMA $n^{\circ}$ 274/00; CONAMA $n^{\circ}$ $357 / 05$ ). One should note, however, that these laws recommend the analysis of 15 samples and annual monitoring, so the results shown here should only be considered indicative.

Despite these results for the water, the Thermotolerant coliform densities of the mussel samples collected in August and September on Urubuqueçaba Island were considered inappropriate as they exceeded the indicative limit in force (resolution ANVISA n ${ }^{\circ} 12 / 01$ ).

Enterococci densities in the water samples from Urubuqueçaba Island varied from 23 to $79 \mathrm{CFU}$ $100 \mathrm{ml}^{-1}$, with a mean value of $43.8( \pm 23.41)$, while the samples from Porchat Island varied from 30 to 80 CFU $100 \mathrm{ml}^{-1}$, with a mean value of $369.36( \pm 507,93)$. The mussels samples showed Enterococci densities varying from 17 to $1515 \mathrm{CFU} \mathrm{g}^{-1}$ for Urubuqueçaba Island, with a mean value of $858.6( \pm 658,12)$ and from 49 to $1272 \mathrm{CFU} \mathrm{g}^{-1}$ for Porchat Island, with a mean value of $369.36( \pm 507.93)$ (Fig. 3).

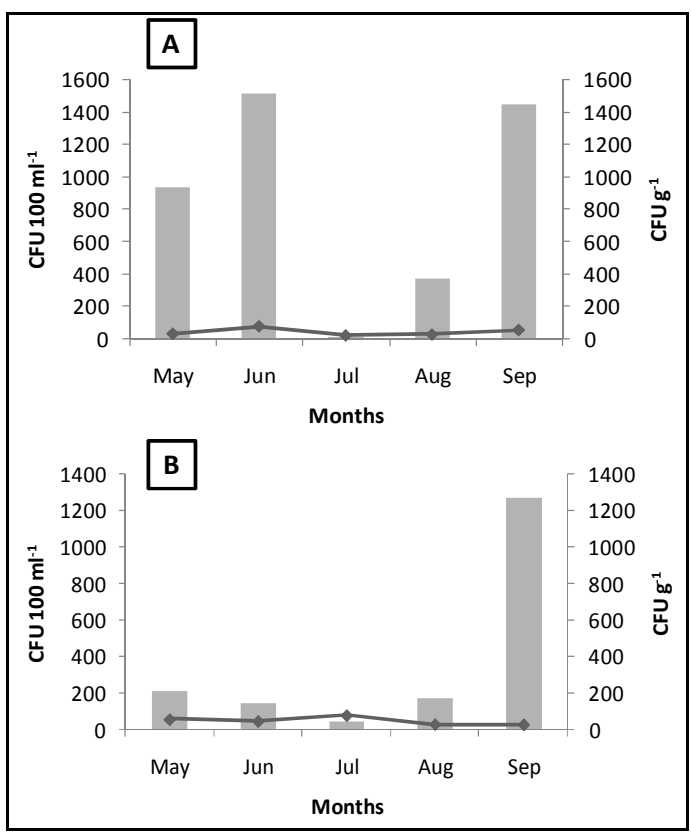

Fig. 3. Enterococci densities obtained during the study. a) Samples from Urubuqueçaba Island. b) Samples from Porchat Island. Lines represent the results for water samples $\left(\mathrm{CFU} 100 \mathrm{ml}^{-1}\right)$ and the bars represent the results for the mussels ( $\mathrm{CFU} \mathrm{g} \mathrm{g}^{-1}$ ).

In this study, the densities of Enterococci were always higher than those of Thermotolerant coliforms. Also, the bacterial densities obtained from the mussel samples were 50 to 4,300 times higher than those obtained from the water (Table 1).

Table 1. Relative fecal indicator bacteria obtained dividing the values of bacterial densities found in the mussels samples by the densities in the water samples. PI and UI stands for Porchat Island and Urubuqueçaba Island, respectively. Subscripts $w$ and $m$ indicate water and mussels sample, respectively. -: No fecal bacteria detected. *: Only occurrence of water's bacterial density higher than the mussels'.

\begin{tabular}{c|cccc}
\hline \hline \multirow{2}{*}{ Months } & \multicolumn{2}{|c}{$\begin{array}{c}\text { Thermotolerant } \\
\text { coliforms }\end{array}$} & \multicolumn{2}{c}{ Enterococci } \\
\cline { 2 - 5 } & $\mathbf{P I}_{\mathbf{m}} / \mathbf{P I}_{\mathbf{w}}$ & $\mathbf{U I}_{\mathbf{m}} / \mathbf{U I}_{\mathbf{w}}$ & $\mathbf{P I}_{\mathbf{m}} / \mathbf{P I}_{\mathbf{w}}$ & $\mathbf{U I}_{\mathbf{m}} / \mathbf{U I}_{\mathbf{w}}$ \\
\hline May & - & - & 363.10 & 2847.27 \\
Jun & $*$ & 222.22 & 300.62 & 1917.34 \\
Jul & 54.95 & 100.00 & 61.13 & 72.00 \\
Aug & 1178.57 & 2015.50 & 548.71 & 1307.37 \\
Sep & 803.28 & 1302.33 & 4310.85 & 2589.11 \\
\hline
\end{tabular}


Linear regression analyses revealed that there was no statistically significant relationship between the bacterial densities of the water and mussel samples from Porchat Island; such a relationship was, however, found for Urubuqueçaba Island, for Enterococci $(\mathrm{p}=0.0438)$ and also for Thermotolerant coliform densities $(\mathrm{p}=0.0138)$.

For the clearance rate determination experiments, results showed that bacteria were removed more efficiently between the time intervals of two to three hours after they had been inoculated in the mussels' flasks. Clearance rates calculated for this time interval ranged from $468.31 \mathrm{ml} \cdot \mathrm{h}^{-1}$, for the biggest size class, to $162.98 \mathrm{ml} . \mathrm{h}^{-1}$, for the smallest size class (Table 2). The mean clearance rate was $317.7 \mathrm{ml} \cdot \mathrm{h}^{-1}$.

Table 2. Clearance rates and retention efficiency for the different size classes during the period when bacterial numbers decay was higher.

\begin{tabular}{ccc}
\hline \hline Mussels' size (cm) & $\begin{array}{c}\text { Clearance } \\
\text { rates (ml.h }\end{array}$ & $\begin{array}{c}\text { Retention } \\
\text { efficiency (\%) }\end{array}$ \\
\hline$<\mathbf{3 . 5}$ & 162.98 & 27.82 \\
$\mathbf{3 . 5}-\mathbf{4 . 0}$ & 318.04 & 47.06 \\
$\mathbf{4 . 0}-\mathbf{4 . 5}$ & 380.09 & 53.24 \\
$\mathbf{4 . 5}-\mathbf{5 . 0}$ & 259.09 & 40.44 \\
$>\mathbf{5 . 0}$ & 468.31 & 60.81 \\
Mean & 317.7 & 45.87 \\
\hline
\end{tabular}

Applying the least squares regression to these results, an allometric relation was obtained (Fig. 4), the parameters $a$ and $b$ for the equations of which were, respectively, 28.3229 and 1.6421. Hence, the clearance rates $(C R)$ was related to the mussels' size $(L)$ by the allometric equation $C R=28.3229 L^{1.6421}$.

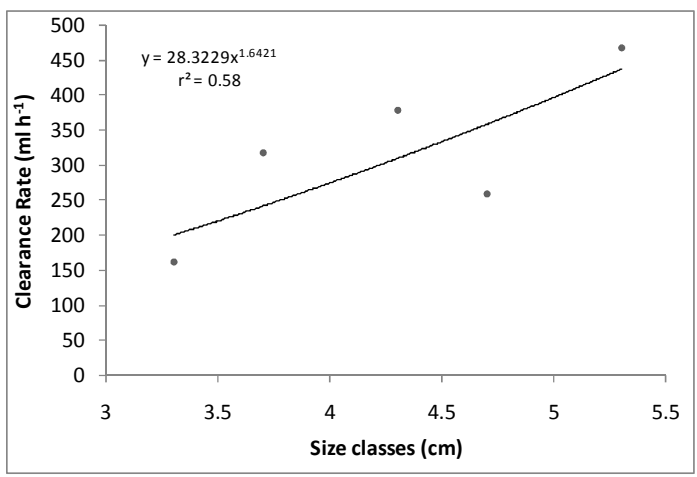

Fig. 4. Exponential curve adjusted to the clearance rates data $\left(\mathrm{ml}^{-1} \mathrm{~h}^{-1}\right)$ in relation to the mussels' size classes (shell length, in $\mathrm{cm}$ ).

\section{DisCUSSION}

The results obtained in this study showed that $P$. perna has the potential for accumulating many bacteria due to filter feeding, although phytoplankton is considered the most important item in bivalve feeding (CHARLES et al., 1999). Despite of bacterial retention ability of $P$. perna, the relationship between the number of bacteria in the water column and the bacteria accumulated by the mussel is not straightforward and depends on many factors, difficult to evaluate.

The bacterial densities found in mussels are the result of complex interactions related to the physiology and morphology of the bivalve such as size, filtering, excretion, and metabolic rates (SOLÉ et al., 2000) and also depend on prey characteristics such as size, specific composition and density of the bacteria in the water. These latter are affected by several environmental conditions such as solar irradiation, temperature, salinity, and nutrient availability (SINTON et al., 2002).

The higher levels of fecal contamination in mussels obtained from Urubuqueçaba Island may be explained by the size of the mussels from this area since they were usually bigger than those from Porchat Island. In fact, the clearance experiments showed that bacterial retention is positively correlated with the size of the mussels. On the other hand, it is probable that the waters of Urubuqueçaba Island are chronically more contaminated, thus presenting higher densities of fecal bacteria due to the location of this sampling site. The island's proximity to the coast and, consequently, to the city, means that these waters are subject to contamination by illegal sewage discharge and/or by urban drainage waters, considered to be the main causes of the contamination of coastal waters, especially after periods of rain (DWIGHT et al., 2002; OLIVEIRA; PINHATA, 2008).

This may also explain the statistically significant relationship found between the fecal bacteria densities of the water and those of the mussels at Urubuqueçaba, while the contamination at Porchat Island, where the mussels' contamination levels suggests that this site is, on a chronic time scale, less polluted, must be related to isolated events.

The analysis of fecal indicator bacteria in sessile filtering organisms such as the mussel $P$. perna may reveal chronic contamination, differently from the determination of the extremely variable fecal bacteria densities in water samples which point only to acute contamination. In fact, De Donno et al. (2008) ,in a study of the mussel Mytilus galloprovincialis as an indicator of microbiological pollution, suggested that the biological characteristics of the mussel may reveal contamination events that might be missed by water 
monitoring. Guillon-Cottard et al. (1998), who studied the presence of fecal contamination in mussels from a harbor area, also suggest that mussels may be used as fecal contamination monitors.

Alternative ways to evaluate the pollution of water and biological matrices seem promising and should be better assessed. The microbiological quality of mussels of the species $P$. perna may be a useful tool for helping in the monitoring of the microbiological quality of water, the management of the uses of coastal waters and the evaluation of sanitation programs.

However, to achieve this objective, future research should focus on the processes that lead to the accumulation of fecal bacteria in a mussel's tissues. This study attempts to provide another contribution by investigating $P$. perna clearance rates when bacteria were offered as food.

The clearance rates obtained for $P$. perna in this study (from 0.16 to $0.471 \mathrm{~h}^{-1}$ per mussel), were lower than those obtained by Resgalla Jr. et al. (2006), however, these latter authors offered phytoplanktonic organisms to the mussels, so it was already expected that the clearance rates obtained by the use of bacterial cells would be lower since the size of the food offered greatly affects the results, as showed by Lucas et al. (1987).

The parameters of the equation that explains the allometric relation between the clearance rates (CR) and the size of the mussels (L) were rather different from those obtained by Berry and Schleyer (1983). While in this present study the values for a and $\mathrm{b}$ were 28 and 1.6, respectively, the authors quoted had obtained values of $\mathrm{a}=0.0027$ and $\mathrm{b}=1.86$. Again, methodological differences are involved, since those authors did not use bacteria, along with other differences that may be related to the mussel population.

Assuming that the bacterial concentration in a mussel $(\mathrm{Cm})$ is, primarily, a function of the bacterial concentration in the water $(\mathrm{Cw})$ and of the rate at which bacterial cells are removed by the mussel (measured by $\mathrm{CR}$ ), it may be established that $\mathrm{Cm}=\mathrm{Cw}$ $\left(28.3229 L^{1.6421}\right)$.

We are aware that this relation is also a function of time and that the equations shown here are still too simple to account for all the processes that are involved in the accumulation of bacteria in mussel tissues, but future research may allow the development of more refined algorithms for the extrapolation of $\mathrm{Cm}$ from $\mathrm{Cw}$, which may also be very important for establishing new health safety limits for waters in which shellfish are harvested.

In Brazil, the densities of Thermotolerant coliforms, Escherichia coli and Enterococci are used as parameters for specific normative instructions that determine the classification of recreational waters according to their contamination levels, such as the resolution CONAMA $n^{\circ} 274 / 00$, of the national environmental council.

Some of these laws, such as the CONAMA resolution $n^{\circ} 357 / 05$, however, consider only E. coli and Thermotolerant coliforms and do not adopt Enterococci as a parameter, even though this group is considered to be a better indicator than coliforms for marine environments (CABELLI, 1983).

The normative instruction that regulates microbial standards in foodstuffs, including seafood, is the resolution from the national agency of sanitary vigilance, ANVISA, RDC $\mathrm{n}^{\circ}$ 12/01. Although belonging to the marine environment, fish, mussels, crustaceans and other organisms used as food have their microbiological quality evaluation based only on densities of coliforms, staphylococci and Salmonella sp.

Considering the presence of the high bacterial densities observed in this study in some mussel samples even when the surrounding waters presented no restrictions, the classification of water appropriate for shellfish culture becomes a pressing concern. In Brazil, this classification is based only on the presence of fecal bacteria in the water, but this may not be sufficient to guarantee the product's quality. Wilson and Moore (1996) have shown that this criterion is not enough to ensure safety regarding pathogenic bacteria and, especially, the accumulation of viruses. The present study corroborates these authors' conclusions. In our view, safe limits will only be truly established when the formulation of the respective laws takes biological processes and the characteristics of the organisms involved into consideration and when they are in fact based on scientific risk assessment.

Moreover, another worrying fact is that the specific laws in Brazil do not consider Enterococci as a microbiological criterion for the assessment of shellfish culture waters or for shellfish consumption. Considering that this group of bacteria can cause diseases and that they are considered to be better indicators of fecal contamination in sea waters (CABELLI, 1983) and in shellfish and other kinds of food (MARINO et al., 2005; TURANTAS, 2002), new limits for the densities of Enterococci in harvesting waters and in mussel flesh should be elaborated.

Although the demand for the establishment of specific microbiological parameters exists, further attention should be given to this question as adequate standards will only be achieved with the advance of knowledge on how bacteria are accumulated by mussels. This means that, besides clearance rates, other biological processes, such as excretion and digestion of bacterial cells by the filtrating organisms should be the topics of future research. 


\section{ACKNOWLEDGEMENTS}

We would like to thanks the finnancial support granted by FAPESP (Fundação de Amparo à Pesquisa do Estado de São Paulo).

\section{REFERENCES}

APHA- American Public Health Association. Standard methods for the examination of water and wastewater. 21th Edition. APHA, AWWA, WEF. , 2005. $1120 \mathrm{p}$

BERRY, P. F.; SCHLEYER, M. H. The brown mussel Perna perna on the Natal coast, South Africa: utilization of available food and energy budget. Mar. Ecol. Progr. Ser., v. 13, p. $201-210,1983$.

CABELLI, V. J. Health effects criteria for marine recreational waters. Research Triangule Park, USEPA. EPA-600/1-80-031, 1983.98 p.

CETESB. Relatório de qualidade das águas litorâneas do Estado de São Paulo: balneabilidade das praias 2005 São Paulo: 2006

CHARLES F.; AMOROUX, J. M.; GRÉMARE, A. Comparative study of the utilization of bacteria and microalgae by the suspension feeding bivalve: Callista chione. J. mar. biol. Ass. U. K., v. 79, p. 577 - 584, 1999.

COLLINS, A.; STAPLETON, M.; WHITMARSH, D. Fishery-pollution interactions: A modelling approach to explore the nature and incidence of economic damages. Mar. Pollut. Bull., v. 36, p. 211 - 221, Mar. 1998.

DE DONNO, A.; LIACI, D.; BAGORDO, F.; LUGOLI, F.; GABUTTI, G. Mytilus galloprovincialis as a bioindicator of microbiological pollution of coastal waters: A study conducted in the Salento Peninsula (Italy). J. coast. Res., v. 24, p. 216 - 221, 2008.

DWIGHT, R. H.; SEMENZA, J. C.; BAKER, D. B.; OLSON, B. H. Association of urban runoff with coastal water quality in Orange County, California. Wat. environ. Res., v. 74, n. 1, p. 82 - 90, 2002.

GUILLON-COTARD, I.; AUGIER, H.; CONSOLE, J. J.; ESMIEU, O. Study of microbiological pollution of a pleasure boat harbour using mussels as bioindicators. Mar. environ. Res., v. 45, n. 3, p. 239 - 247, 1998.

HOBBIE, J. E.; DALEY, R. J.; JASPER, S. Use of nuclepore filters for counting bacteria by fluorescence microscopy. Appl. environ. Microbiol., v. 33, n. 5, p. 1225 - 1228, 1977.

JORGE, L. C.; GARCIA, L. M.; MARTINS, V. B ; KOSAWA, A.; PAULS, E. Interações dos processos sócio-ambientais nas bacias das enseadas de Icaraí e São Francisco, Niterói (RJ). 2. Organismos aquáticos como bioindicadores da qualidade ambiental com enfoque no mexilhão Perna perna (Linnaeus, 1798), em Niterói-RJ. Mundo \& Vida, v. 3, n. 2, p. 108-116, 2002.
LUCAS, M. I.; NEWELL, R. C.; SHUMWAY, S. E.; SEIDERER, L. J.; BALLY, R. Particle clearance and yield in relation to bacterioplankton and suspended particulate availability in estuarine and open coast populations of the mussel Mytilus edulis. Mar. Ecol. Progr. Ser., v. 36, p. 215 - 224, 1987.

MARINO, A.; LOMBARDO, L.; FIORENTINO, C.; ORLANDELLA, B.; MONTICELLI, L.; NOSTRO, A.; ALONZO, V. Uptake of Escherichia coli, Vibrio cholerae non-O1 and Enterococcus durans by, and depuration of mussels (Mytilus galloprovincialis). Intern. J. Food Microbiol., v. 99, p 281 - 286, 2005.

OLIVEIRA, A. J. F. C.; HOLNAGELL, H. C.; MESQUITA, H. S. L.; FONTES, R. C. F. Physical, chemical and microbiological characterization of intertidal sediments of Pereque Beach, Guarujá (SP), Brazil. Mar. Pollut. Bull., v. 54, p. 921-927, 2007

OLIVEIRA, A. J. F. C.; PINHATA, J. M. W. Antimicrobial resistance and species composition of Enterococcus spp. isolated from waters and sands of marine recreational beaches in Southeastern Brazil. Wat. Res., v. 42, p. 2242-2250, 2008

RESGALLA JR., C.; BRASIL, E. S.; SALOMÃO, L. C. Physiological rates in different classes of sizes of Perna perna (Linnaeus, 1758) submitted to experimental laboratory conditions. Braz. J. Biol., v. 66, p. 325 - 336, 2006.

SINTON, L.W.; HALL, C. H.; LYNCH, P. A.; DAVIESCOLLEY, R. J. Sunlight inactivation of fecal indicator bacteria and bacteriophages from waste stabilization pond effluent in fresh and saline waters. Appl. environ. Microbiol., v. 68, n. 3, p. 1122-1131, 2002.

SOLÉ, M.; PORTE, C.; BARCELO, D.; ALBAIGES, J. Bivalves residue analysis for the assessment of coastal pollution in the Ebro Delta (NW Mediterranean). Mar. Pollut. Bull., v. 40, p. $746-753,2000$

SOLIC, M.; KRSTULOVIC, N.; JOZIC, S.; CURAC, D. The rate of concentration of faecal coliforms in shellfish under different environmental conditions. Environment Int., v. 25, n. 8, p. 991-1000, May 1999.

TURANTAS, F. Incidence of faecal streptococci as an indicator of sanitation in ice-cream and frozen vegetables. Int. J. Food Sci. Technol., v. 37, p. 239243, 2002.

WHO. Guidelines for safe recreational waters - Water Environments. V. 1: Coastal and Fresh-Waters. WHO/EOS/98.14. Geneva: 1998. 208 p.

WILSON, I. G.; MOORE, J. E. Presence of Salmonella spp. and Campylobacter spp. in shellfish. Epidemiol. Infection, v. 116, p. 147 - 153, 1996.

(Manuscript received 26 February 2009; revised 23 June 2009; accepted 25 August 2009) 